\title{
Seed bank dynamics and restoration of Ibodi monkey forest reserve, Southwestern Nigeria
}

\author{
Ademayowa Adenike ODELEYE ${ }^{1}$, Damilare Stephen AKINYEMI ${ }^{1,3,4}$, Olusanya Abiodun \\ OLATUNJI $^{1,2,4}$, Emmanuel Timilehin KOMOLAFE ${ }^{1,5^{*}}$ and Samson Olajide OKE ${ }^{1}$ \\ ${ }^{I}$ Department of Botany, Faculty of Science, Obafemi Awolowo University, PMB 220005, Ile Ife, Nigeria. \\ ${ }^{2}$ Key Laboratory of Mountain Ecological Restoration and Bioresource Utilization \& Ecological Restoration \\ Biodiversity Conservation Key Laboratory of Sichuan Province, Chengdu Institute of Biology, Chinese \\ Academy of Sciences, Chengdu 610041, People's Republic of China. \\ ${ }^{3}$ State Key Laboratory of Vegetation and Environmental Change, Institute of Botany, Chinese Academy of \\ Sciences, Beijing, China. \\ ${ }^{4}$ University of Chinese Academy of Sciences, Beijing, 100039, People's Republic of China. \\ ${ }^{5}$ Department of Botany, Faculty of Science, University of Ibadan, PMB 5116, Ibadan, Oyo State, Nigeria. \\ "Corresponding author; E-mail: komolafete@gmail.com; Tel.: +2347062319435
}

\begin{abstract}
Ibodi Monkey forest reserve (IBMFR) is known for its rich flora and fauna, mainly contributed by regrowth forest species. However, intensive anthropogenic interferences such as agriculture, illegal mining and selective exploitation over a large extent of these ecosystems in the past years have led to a serious depletion of forest's diversity. Consequently, restoration of IBMFR has become a high priority for ecological management of forest. The distribution of soil seed bank in three different physiognomies, (natural regrowth forest, cocoa plantation and tree fallow) at Ibodi monkey forest were investigated. Six sample plots, each $25 \mathrm{~m}$ x $25 \mathrm{~m}$, from each physiognomy were chosen for this investigation. Seasonal variation of seed bank density at various soil depths were carried out by using soil auger to bring soil samples out from 0-15 cm (topsoil) and 15-30 cm (subsoil) and seedling emergence monitored. The total seed density at $0-15 \mathrm{~cm}$ depth was significantly $(\mathrm{p}<0.05)$ higher than the seed bank density at $15-30 \mathrm{~cm}$ depth in both seasons. Seed density varied from 288 seeds $/ \mathrm{m}^{2}$ to 768 seeds $/ \mathrm{m}^{2}$ in rainy season and $288 \mathrm{seeds} / \mathrm{m}^{2}$ to 1287 seeds $/ \mathrm{m}^{2}$ in the dry season. Seed bank density was significantly $(\mathrm{p}<0.05)$ higher in dry season compared with rainy season in regrowth forest and tree fallow physiognomies. This study revealed seeds are more concentrated in the upper soil layer than the lower soil layer in the three physiognomies, with relatively large number of herbaceous species compared with woody species. The seedbank may not be sufficient to restore the forest reserve. Additional management actions, such as active seed sowing of target species, may be necessary.

(c) 2018 International Formulae Group. All rights reserved.
\end{abstract}

Keywords: Disturbance, physiognomy, seed, season.

\section{INTRODUCTION}

Natural forests in the tropics are continuously being subjected to natural and human disturbances, which have resulted in their degradation, disruption of ecosystem functioning and loss of biodiversity (Prance et 
al., 2000; Sanderson et al., 2004; MartínezRamos et al., 2016). The majority of this forest have been extensively degraded in other to pave ways for other land uses such as industrial estate, crop fields and/or plantations (Prance et al., 2000). The degradation of forest ecosystem is usually accompanied by species extinction, reduction in biodiversity and decrease in primary productivity (Martínez-Ramos et al., 2016; Gbetoho et al., 2017). Currently, an estimated 850 million hectares of degraded forests exist globally. At regional level, Africa suffered the second largest net loss of forests between 2000 and 2010 - about 3.4 million hectares per year (FAO, 2010). In Nigeria, the tropical rainforests have been under pressure from among others, extensive logging, grazing and infrastructural development as a result of population growth. FAO (2010) reported Nigeria as one of the largest countries with annual net loss of $3.7 \%$. However, on global basis, efforts have been geared towards ecological restoration of ecosystems impacted by human disturbance (Golos et al., 2016) with current global targets expected at restoring $15 \%$ of degraded ecosystems by 2020 (CBD, 2012), hence the need for an effective and low-cost forest and biodiversity restoration methods.

Soil seed bank as the total number or density of viable seeds stored in the soil in a given period, could give a mirror- image of the population that persisted in incubation, and also laid the groundwork for the recruitment, regeneration and persistence of a population (Cabin and Marshall, 2000; Cabin et al., 2000). Soil seed banks enhance the prospect of plants to disperse through time, with fundamental implications for community dynamics, as acknowledged by ecological and evolutionary theory, and documented in several empirical studies (Vandvik et al., 2016). On ecological time-scales, seed banks are essential for forests growth as it exemplify local 'biodiversity reservoirs' which can contribute to local population persistence and maintenance of biodiversity through historical storage of remnant populations and the maintenance of a functionally diverse belowground species pool available for germination in response to environmental variability or change (Vandvik et al., 2016). It also reflects evolutionary changes in plant communities as a consequence of changes in land use (Greene and Waters, 2001) besides serving as safeguards for genetic variability. Hence, the study on soil seed banks is very crucial in disentangling its roles in community and population dynamics, conservation as well as in understanding of basic ecological patterns and processes (Alexander et al., 2012; Vandvik et al., 2016), because seeds on germinating, form part of a future generation (Olatunji et al. 2015). Nevertheless, the composition of the seed bank is most often governed by several factors such as the structure and production of the present and previous plant communities, spatial and temporal in soil seed bank, Seasonal variation as well as the longevity of the seed of each species under local biotic and abiotic conditions (López-Marinò et al., 2000). A number of earlier studies had demonstrated soil seed bank to be extant vegetation dependent, which may be a major determinant of spatial and temporal environmental variations in soil seed bank composition (Yan et al., 2009). Seasonal variation in seed density at sites of varying physiognomy might be related to climatically seasonal changes as seeds of some species show strong seasonal shifts in density. In addition, studies had reported that the seasonal variation and seed burial is vital for long-term population and community dynamics by fostering the formation of a persistent soil seed bank (De Villers et al., 2002; Lopez, 2003; Caballero et al., 2005). As conscious efforts are being geared towards preventing total destruction of the forest ecosystem and ensuring the conservation of its rich biodiversity, an understanding of soil seed bank dynamics in relation to depths and seasons under different physiognomies is essential in deciding 
whether intervention is needed to assist the natural regeneration process of degraded forest ecosystems.

Although researchers have investigated seasonal variation and soil seed bank dynamics in different ecosystem, none has been recorded in Ibodi Monkey forest which is one of the forest reserves and a tourist attraction in Nigeria. Therefore, considering the significance of this forest and the alarming rate of forest degradation in Nigeria, we selected three different physiognomies; Natural regrowth forest, Cocoa plantation and tree fallow and examined their soil seed bank composition. This study aimed to investigate the present status of the soil seed bank of Ibodi Monkey forest and its potential for restoration. We investigated: (i) species composition and density of the soil seed bank among the physiognomies, (ii) effect of seasonality on the seed bank density among the physiognomies, and (iii) effects of soil depths on the seed bank composition of the physiognomies.

\section{MATERIALS AND METHODS \\ Study sites}

The study was carried out in Ibodi Monkey Forest in Osun State, Southwest Nigeria which lies between latitudinal and longitudinal central point of $7^{\circ} 35^{\prime} \mathrm{N}$ and $4^{\circ}$ $40^{\prime} \mathrm{E}$ (Figure 1). The site is a typical tropical lowland rainforest. Though slightly modified as a result of human activities, the three layers of the forest (topmost, middle and lower) could still be identified. Ibodi Monkey forest has a tropical climate with prominent rainy and dry seasons. The rainy season generally occurs between March and October while the dry season occurs between November and February yearly. Ibodi has an average annual rainfall of $1157 \mathrm{~mm} / \mathrm{yr}$ and Average annual temperature of $26.1^{\circ} \mathrm{C}$ (Climate-Data.org (http://climate-data.org/). As a result of continuous weathering, the soil of the study site is ferruginous (ferric luvisols) tropical soil which is a prominent feature in many uplands part of Southwestern Nigeria (FAO/UNESCO, 1988). The area is gently undulating, plain and the underlying rock, which is gneissose, is crystalline and found in the basement complex.

\section{Sampling procedure}

Three distinct study physiognomies: Natural regrowth forest, Cocoa plantation and Tree fallow (A, B, and $\mathrm{C}$ respectively) were identified in the forest during the reconnaissance survey. Six sample plots, each of $25 \mathrm{~m} \mathrm{x} 25 \mathrm{~m}$ were randomly chosen from the three distinct physiognomies, using a measuring tape and demarcated with wooden pegs. To avoid edge effect, at least $10 \mathrm{~m}$ was left as set back before marking out any plot.

\section{Assessments of the above ground vegetation}

Assessment of the above ground floristic composition of the area were made prior to seed bank study. Diversity and distribution of the plant species were determined using the following parameters: Shannon-Wiener index $\left(\mathrm{H}^{\prime}\right)$, Pielou evenness Index $(J)$, Species richness $(\mathrm{R})$ and Sorenson's index of Similarity (SI).

$$
\begin{aligned}
& \mathrm{H}^{\prime}=-\sum_{i=1}^{s}(p i \cdot \ln p i) \\
& J=\frac{H^{1}}{\ln (S)} \\
& \mathrm{R}=(\mathrm{S}-1) / \log \mathrm{N} \\
& \mathrm{SI}=\frac{2 \mathrm{~J}}{A+B}
\end{aligned}
$$

Where $\mathrm{N}$ represents the total number of all types of individual species; $\mathrm{Ni}$ represents the number of individuals of a species i; Pi represents the ith species in the proportion of the total number of species; $\mathrm{J}$ represents species occurring in both communities.

\section{Seedlings emergence test}

In all the six study plots, a total of 140 soil samples were randomly collected 
during the dry (December, 2013) and rainy (June, 2014) seasons at two different depths of 0-15 cm (topsoil) and 15-30 cm (subsoil) using a soil auger of $8.5 \mathrm{~cm}$ in diameter. Soil samples were air dried at room temperature and spread out in perforated plastic plates (to allow excess water drain out) in the screen house where they were watered daily and monitored for seedling emergence. All seedlings from the germinated seeds were identified every week up to six months period. When seedlings emerged, they were pulled out and the roots were rinsed into the plate to avoid unidentified seeds from being lost. During this period, soil samples were stirred as often as possible to bring any nongerminated seed within soil depth to the surface in order to increase the possibility of seeds to be exposed to light (Olatunji et al., 2015). Seedling emergence study was done with a view to determining the density and species composition of the seed bank of the study plots. Total number of emerged seedlings was used to quantify the viable seed and the ability of the soil seed bank to contribute to vegetation restoration.

\section{Statistical analysis}

The data obtained for seedling numbers were transformed prior to the statistical analysis for normality of the data using log transformation. Two- way Analysis of Variance was used to test for any significant difference in the soil seed bank among the three sites in different seasons and at different depths. The number of seedlings that emerged per centimeter $(\mathrm{cm})$ area was transformed to per meter (m) using the method of Mayor and Pyott (1966).

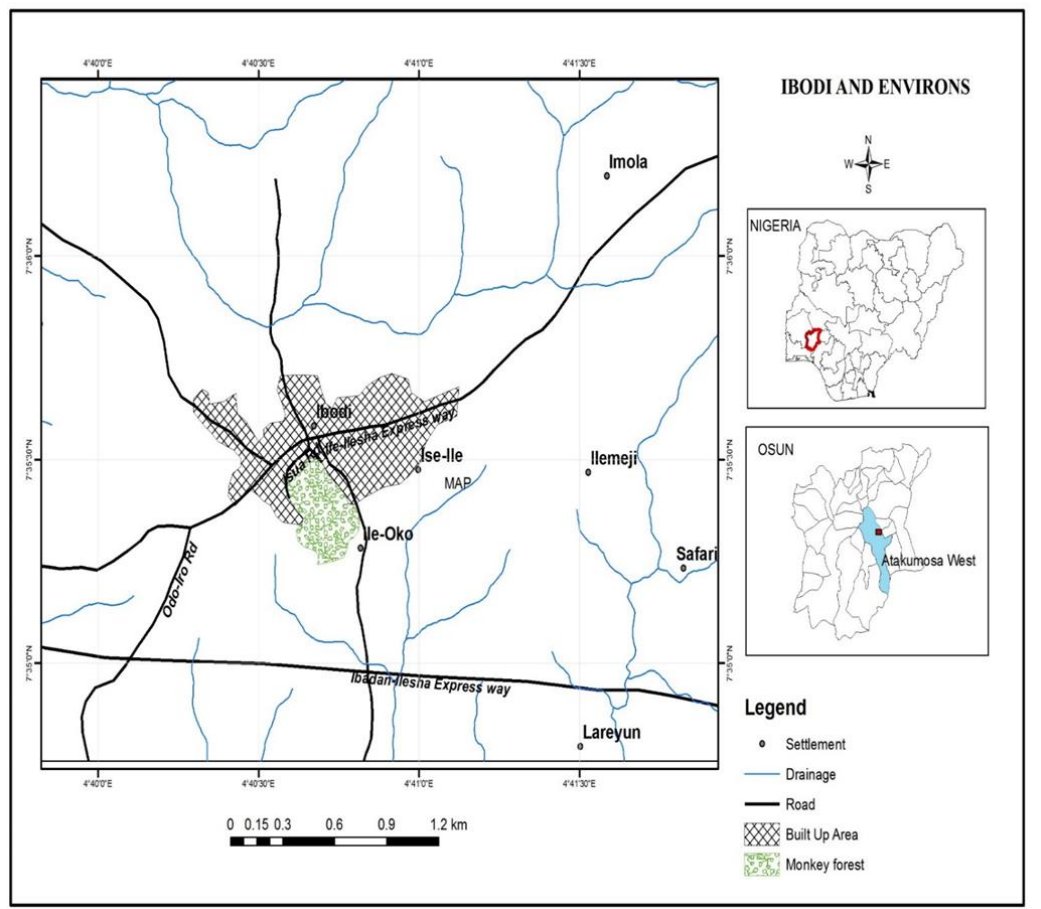

Figure 1: Ibodi Monkey forest located at Atakumosa West Local Government Area of Osun State, Nigeria. 


\section{RESULTS}

\section{Biodiversity of the above ground vegetation}

A total of 163 plant species were identified in the three selected physiognomies in Ibodi Monkey forest. These belonged to 57 families and 129 genera. Rubiaceae (15 Species), Apocynaceae and Fabaceae (11 Species each), Moraceae and Sterculiaceae (9 Species each), Asteraceae and Sapindaceae (6 Species each), Acanthaceae, Combretaceae, Euphorbiaceae and Verbenaceae (5 Species each) were the overall diverse families (in terms of species richness) contributing 53.4\% of all the species. Woody Species (Trees and Shrubs) $(57.4 \%)$ were the dominant life form in the study area, followed by climbers (22.2\%), herbs (20.4\%) (Table 1).

Plant species richness in the three physiognomies ranged from 10.82 to 15.81 with the richness highest in the Regrowth forest and lowest in the Cocoa plantation. Shannon-Wiener index $\left(\mathrm{H}^{\prime}\right)$ showed that the Regrowth forest physiognomy had the highest community diversity (3.403) followed by Tree fallow (3.238) with Cocoa plantation having the lowest diversity index (2.501). The result of Pielou evenness index showed values ranging from 0.799 in Cocoa plantation to 0.931 in Regrowth forest and Tree fallow (Table 1).

Sorensen index of similarity showed low similarity among the three physiognomies. However, the Tree fallow and Cocoa plantation physiognomies were the most similar with a similarity index of $40.28 \%$ while the Regrowth forest and Cocoa plantation physiognomies have the least similarity index value at $16.54 \%$ (Table 2).

\section{Species composition of the seed bank germination test}

A total of 34,22 and 24 seedlings species belonging to 18,12 and 13 families emerged from germination test during dry season in physiognomy $\mathrm{A}, \mathrm{B}$ and $\mathrm{C}$ respectively at $0-15 \mathrm{~cm}$ depth (Table 3 ), while at $15-30 \mathrm{~cm}$ depth, 14,7 and 10 seedlings emerged from each respective physiognomy
(A, B and C). The seed bank of physiognomy $\mathrm{A}, \mathrm{B}$ and $\mathrm{C}$ during rainy season contained 24 , 17 and 14 seedlings at $0-15 \mathrm{~cm}$ depth, and 11 , 7 and 9 seedlings at $15-30 \mathrm{~cm}$ depth respectively (Table 3 ).

Furthermore, among the numerous seeds that emerged in the seed bank, herbaceous species exhibited dominance among the physiognomies by constituting $84.18 \%$ in physiognomy $\mathrm{A}, 85.33 \%$ in $\mathrm{B}$ and $92.05 \%$ in $\mathrm{C}$ of the total seed density at $0-15$ $\mathrm{cm}$ depth during the dry season (Table 4). Similarly, at $15-30 \mathrm{~cm}$ depth during the same dry season, herbaceous species dominated the seed bank germination test (Table 4). In the rainy season, the seedling composition of herbaceous species exceeded other habit form among the three physiognomies. Herbaceous species accounted for $61.32 \%, 58.23 \%$ and $86.10 \%$ of the total plant species found physiognomy $\mathrm{A}, \mathrm{B}$ and $\mathrm{C}$ at $0-15 \mathrm{~cm}$ depth respectively (Table 4 ). While at $15-30 \mathrm{~cm}$ depth, herbaceous contributed $69.33 \%$, and $78.80 \%$, to the seed bank germination test of physiognomy A and C respectively (Table 4). However, woody species exhibited dominance by constituting $65.50 \%$ of total emerged seedlings in physiognomy B (Table 4). Some of the herbaceous species that emerged in the three physiognomies include Ageratum conyzoides, Chromolaena odorata, Euphorbia hirta, Euphorbia hyssopifolia, Ipomoea involucrata, Laportea aestuans, Oldenlandia corymbosa, Oxalis corniculata, Pepperomia pellucida, Pouzolzia guineensis, Sida acuta, Sida urens, Spilanthes filicaulis and Synedrella nodifolia (Tables 2-4). Ficus exasperata and Ipomoea involucrata were the only woody and climber species emerged in the three physiognomies (Tables 2-4). In addition, Tables (2-4) showed the mean density (seeds $\left./ \mathrm{m}^{2}\right)$ and Percentage Contribution of individual species in the Seed bank of the three physiognomies in both dry and rainy Season at $0-15 \mathrm{~cm}$ and $15-30 \mathrm{~cm}$ depths. 


\section{Species diversity of the soil seedbank in dry season}

At $0-15 \mathrm{~cm}$ Margalef species richness index was consistent with the standing vegetation richness was highest (5.6625) in Regrowth forest and lowest (4.3640) in Cocoa plantation. However, Shannon Wiener diversity index did not follow the trend in the standing vegetation as it was highest in Cocoa plantation and lowest in Regrowth forest. Also, Pielou evenness index was not consistent with the standing vegetation. At $15-30 \mathrm{~cm}$ depth, Margalef species richness and Shannon Wiener diversity index were highest (2.3376 and 1.8976) respectively at Tree Fallow with lowest values (0.1733 and 0.2430) respectively at Regrowth forest plantation. Cocoa Plantation had intermediate values (1.3896 and 1.4051) respectively (Figure 2).

\section{Species diversity of the soil seedbank in rainy season}

At $0-15 \mathrm{~cm}$ Margalef species richness index was consistent with the standing vegetation richness was highest (5.6625) in Regrowth forest, though lowest (4.3640) in Tree fallow. (Figure 3) However, Shannon Wiener diversity index follow the trend in the standing vegetation as it was highest in Regrowth forest and lowest in Cocoa plantation. Also, Pielou evenness index was not consistent with the standing vegetation. At $15-30 \mathrm{~cm}$ depth, Margalef species (2.3161) richness and Shannon Wiener diversity index (2.18) were highest at Regrowth forest with lowest values (1.78 and 1.30) respectively at Cocoa plantation. Tree fallow had intermediate values (2.18 and 1.85) respectively (Figure 3).

\section{Depth distribution of the soil Seed Bank}

Generally, the vertical distribution of the seed bank among the three physiognomies during rainy and dry season showed a decrease in seed density with increase in depths (Figures 4 and 5). The total seed density at $0-15 \mathrm{~cm}$ depth was significantly (p $<0.05$ ) different from the seed bank density at $15-30 \mathrm{~cm}$ depth. Most of the species in the soil seed bank were found at $0-15 \mathrm{~cm}$ (Figures 4 and 5). Seed bank density of physiognomy A exhibited a declining trend with increasing soil depth. A mean total of 1062 seeds $/ \mathrm{m}^{2}$ and 225 seeds $/ \mathrm{m}^{2}$ emerged at $0-15$ and $15-30 \mathrm{~cm}$ depth during the dry season correspondingly (Figure 4). In physiognomy B, a mean total of 225 and 63 seeds $/ \mathrm{m}^{2}$ emerged at $0-15$ and 15 $30 \mathrm{~cm}$ depths in the dry season samples. While in physiognomy $\mathrm{C}$, a mean total of 864 and 141 seeds $/ \mathrm{m}^{2}$ emerged at $0-15$ and $15-30$ $\mathrm{cm}$ depths respectively (Figure 4). In addition, physiognomy $\mathrm{A}, \mathrm{B}$ and $\mathrm{C}$ had total seed density of 543,201 and 276 seeds $/ \mathrm{m}^{2}$ at $0-15$ cm depth and 225, 87 and 118 at $15-30 \mathrm{~cm}$ depth respectively in rainy seasons)

\section{Monthly and seasonal dynamics in seed bank density}

The total seed density varied from 288 seeds $/ \mathrm{m}^{2}-768$ seeds $/ \mathrm{m}^{2}$ in rainy season and 288 seeds $/ \mathrm{m}^{2}-1287$ seeds $/ \mathrm{m}^{2}$ in the dry season (Figure 6). Total Seed bank density was significantly $(p<0.05)$ higher in dry season compared to rainy season in physiognomy A (Regrowth forest) and C (Tree Fallow). There was no significant difference in total seed density between rainy and dry season in physiognomy B (Figure 6). Furthermore, the seed bank densities among the three physiognomies during the two seasons (rainy and dry season) were significantly different from each other except for cocoa plantation physiognomy. It was visually observed that the monthly seedling emergence during the dry season reached its peak in May in all the study physiognomies, while in the rainy season seedling emergence reached its peak in July in sites A and B but peaked in June in physiognomy C. 


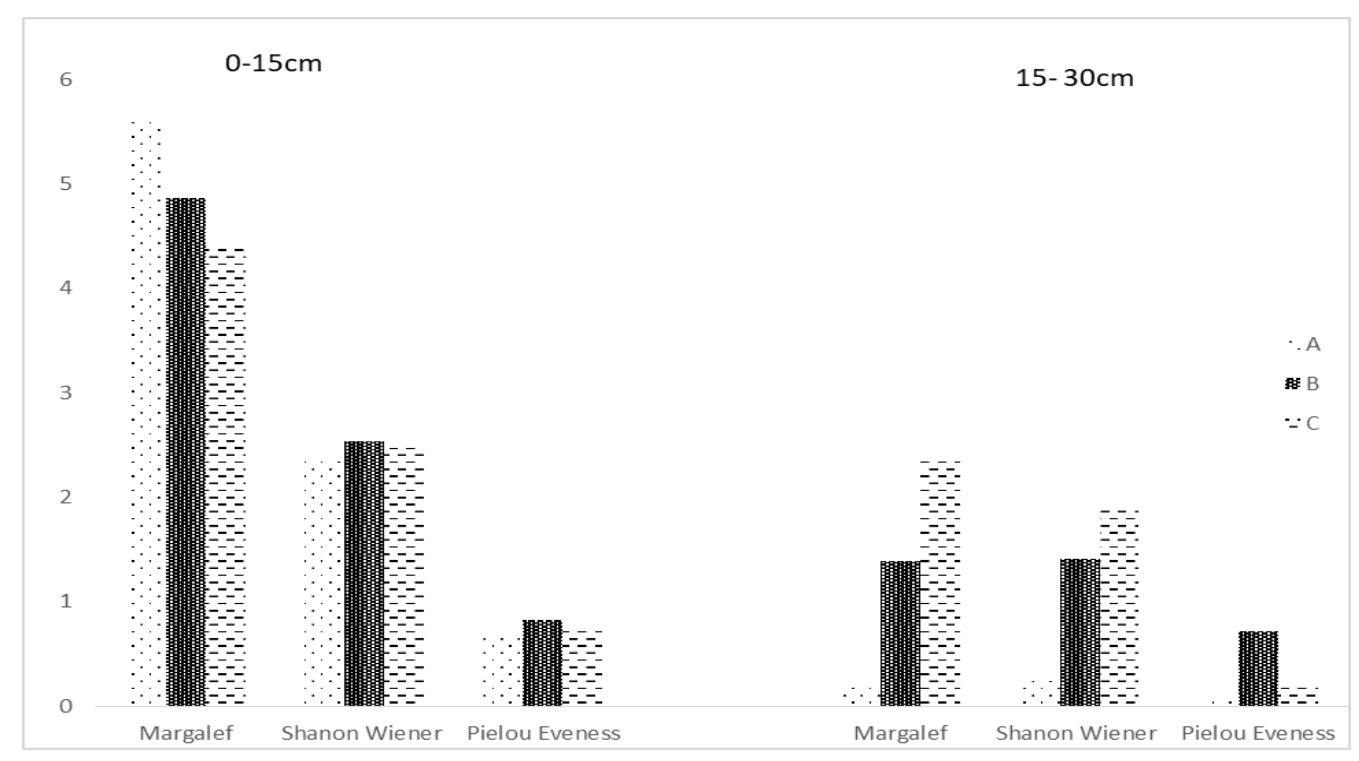

Figure 2: Species diversity indices in the soil seed bank in each physiognomy in dry season. Physiognomy A- Regrowth Forest, physiognomy B- Cocoa plantation, physiognomy C- Tree Fallow.

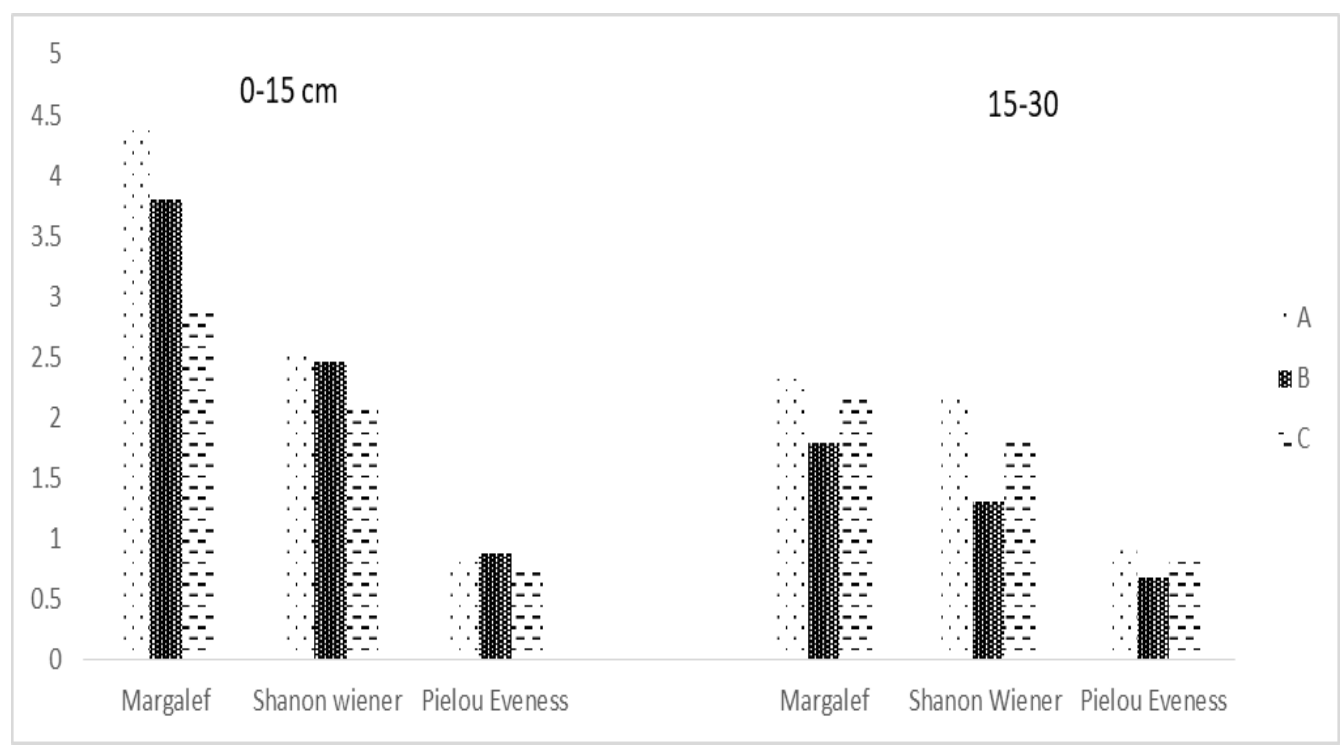

Figure 3: Species diversity indices in the soil seed bank in each physiognomy in rainy season. Physiognomy A- Regrowth Forest, physiognomy B- Cocoa plantation, physiognomy C- Tree Fallow. 


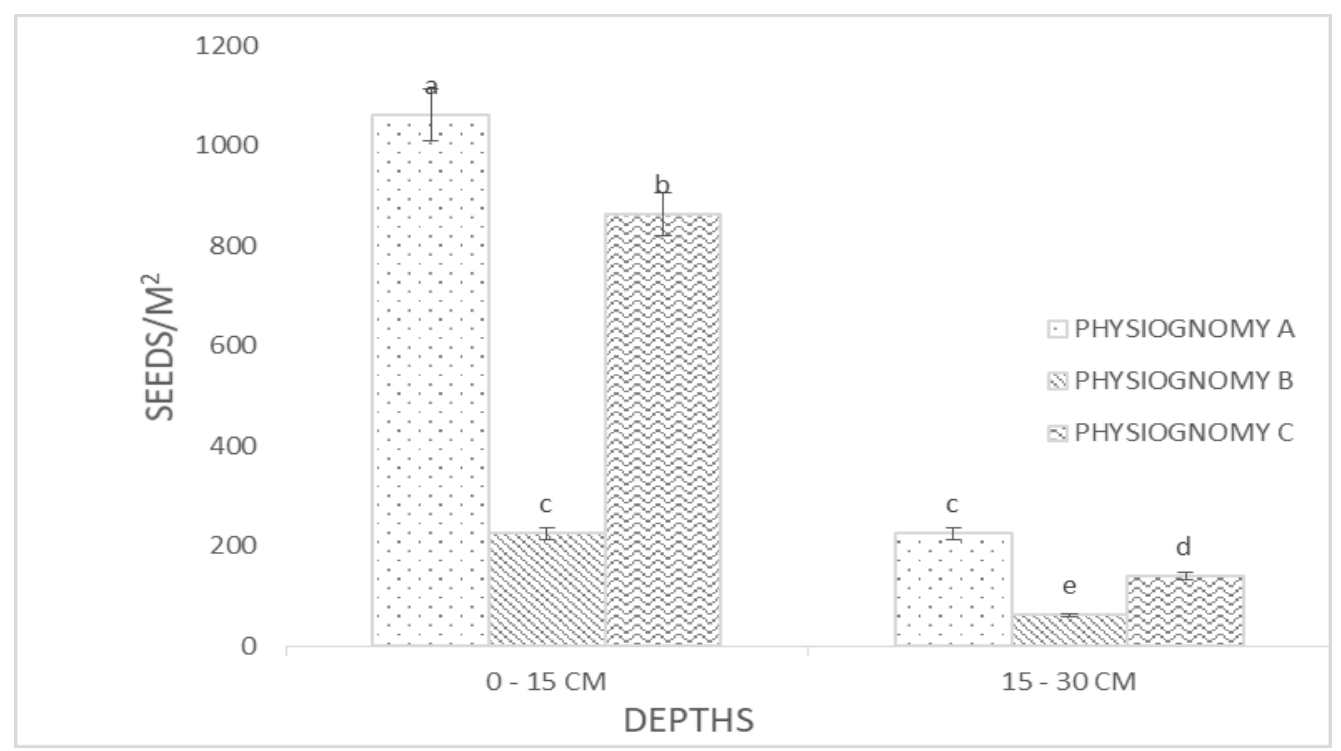

Figure 4: Depth distribution of the Seed density among the Three Study physiognomies in Ibodi Monkey Forest, Osun State during the dry season (mean \pm SE). Means with the different letters at similar soil depth are significantly different at $\mathrm{p}<0.05$ using DMRT physiognomy A- Regrowth Forest, physiognomy B- Cocoa plantation, physiognomy C- Tree Fallow.

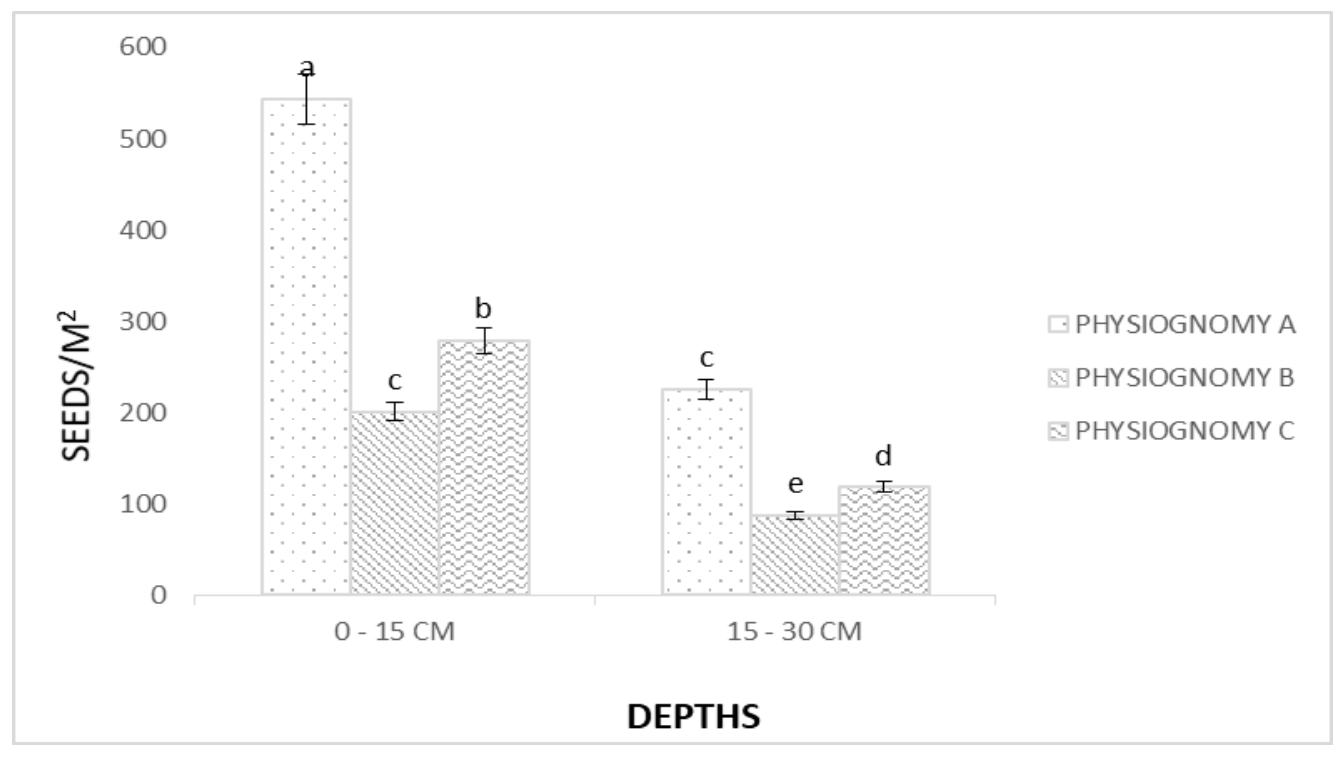

Figure 5: Depth distribution of the Seed density among the Three Study Sites in Ibodi Monkey Forest, Osun State during the rainy season (mean \pm SE). Means with the different letters at similar soil depth are significantly different at $\mathrm{p}<0.05$ using DMRT. physiognomy A- Regrowth Forest, physiognomy B- Cocoa plantation, physiognomy C- Tree Fallow. 


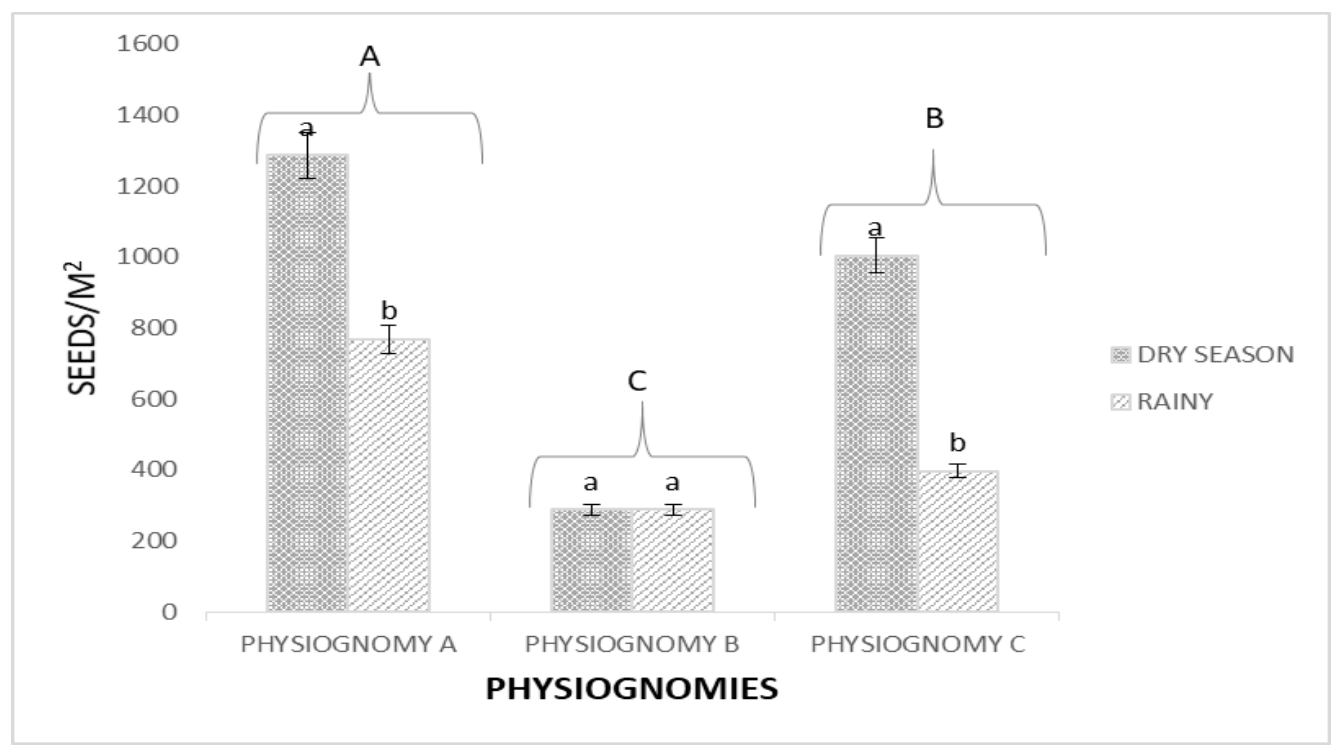

Figure 6: Seasonal Distribution of the seedbank in the three physiognomies (mean $\pm \mathrm{SE}$ ). Means with the different letters at similar soil depth are significantly different at $\mathrm{p}<0.05$ using DMRT physiognomy A- Regrowth Forest, physiognomy B- Cocoa plantation, physiognomy C- Tree Fallow.

Table 1: Margalef, Shannon-Wiener and Pielou evenness indices of the three physiognomies.

\begin{tabular}{lccc}
\hline PHYSIOGNOMIES & $\mathbf{R}$ & $\mathbf{H}^{\prime}$ & $\mathbf{E}$ \\
\hline Regrowth forest & 15.81 & 3.40 & 0.93 \\
\hline Cocoa Plantation & 10.82 & 2.50 & 0.80 \\
\hline Tree fallow & 13.57 & 3.24 & 0.93 \\
\hline $\begin{array}{l}\text { R - Margalef's Species Richness, } \\
\text { H' - Shannon-Wiener species diversity index, } \\
\text { E - Pielou Evenness Index. }\end{array}$ & & \\
\end{tabular}

Table 2: Sorensen's index (\%) of similarity of the three physiognomies.

\begin{tabular}{llll}
\hline PHYSIOGNOMIES & A & B & C \\
\hline A & - & & \\
\hline B & 16.54 & - & \\
\hline C & 21.11 & 40.28 & - \\
\hline A- Regrowth Forest physiognomy, & & \\
B- Cocoa Plantation physiognomy, \\
C- Tree-Fallow physiognomy.
\end{tabular}


Table 3: Family and habit composition of the Emergent seedling in each physiognomy.

\begin{tabular}{|c|c|c|c|c|c|c|c|c|c|c|c|c|c|}
\hline \multirow[b]{3}{*}{$\begin{array}{l}\text { Physiognomie } \\
\text { s }\end{array}$} & \multicolumn{7}{|c|}{ Dry season } & \multicolumn{6}{|c|}{ Rainy season } \\
\hline & \multirow[b]{2}{*}{$\begin{array}{l}\text { Depth } \\
\text { s }\end{array}$} & \multicolumn{8}{|c|}{ Habits } & \multicolumn{4}{|c|}{ Habits } \\
\hline & & $\begin{array}{l}\text { Specie } \\
\text { S }\end{array}$ & $\begin{array}{l}\text { Familie } \\
\text { S }\end{array}$ & $\mathbf{W}$ & $\mathbf{H}$ & G & $\mathrm{C}$ & $\begin{array}{l}\text { Specie } \\
\text { S }\end{array}$ & $\begin{array}{l}\text { Familie } \\
\mathrm{S}\end{array}$ & $\mathbf{W}$ & $\mathbf{H}$ & G & $\mathbf{C}$ \\
\hline $\mathbf{A}$ & $0-15$ & 34 & 18 & 8 & $\begin{array}{l}2 \\
1\end{array}$ & 1 & 4 & 24 & 17 & 5 & $\begin{array}{l}1 \\
4\end{array}$ & 2 & 3 \\
\hline & $15-30$ & 14 & 9 & 1 & $\begin{array}{l}1 \\
2\end{array}$ & 1 & - & 11 & 10 & 2 & 7 & - & 2 \\
\hline B & $0-15$ & 22 & 12 & 1 & $\begin{array}{l}1 \\
7\end{array}$ & 3 & 1 & 17 & 13 & 5 & 9 & 2 & 1 \\
\hline & $15-30$ & 7 & 5 & - & 4 & 2 & 1 & 7 & 7 & 2 & 4 & 1 & - \\
\hline $\mathbf{C}$ & $0-15$ & 24 & 13 & 3 & $\begin{array}{l}1 \\
8\end{array}$ & 4 & 1 & 14 & 9 & 1 & $\begin{array}{l}1 \\
0\end{array}$ & 3 & - \\
\hline & $15-30$ & 10 & 8 & - & 8 & 1 & 1 & 9 & 6 & 1 & 5 & 3 & - \\
\hline
\end{tabular}

W- Woody Species, H- Herbaceous species, G- Grass species, C- Climber species. A- Regrowth Forest physiognomy, BCocoa Plantation physiognomy, C- Tree-Fallow physiognomy.

Table 4: Percentage (\%) habit contribution $\left(\right.$ seeds $\left./ \mathrm{m}^{2}\right)$ in each physiognomy during rainy and dry season.

\begin{tabular}{lccccccccc}
\hline & \multicolumn{4}{c}{ Dry season } & \multicolumn{5}{c}{ Rainy season } \\
\hline & & \multicolumn{3}{c}{ Habits (\%) } & \multicolumn{5}{c}{ Habits (\%) } \\
\hline PHYSIOGNOMIES & Depths & $\mathrm{W}$ & $\mathrm{H}$ & $\mathrm{G}$ & $\mathrm{C}$ & $\mathrm{W}$ & $\mathrm{H}$ & $\mathrm{G}$ & $\mathrm{C}$ \\
\hline A & $0-15$ & 14.13 & 84.18 & 0.28 & 1.41 & 19.34 & 61.32 & 1.66 & 17.68 \\
\hline & $15-30$ & 24.00 & 65.33 & 10.67 & - & 18.70 & 69.33 & - & 12.00 \\
\hline B & $0-15$ & 6.67 & 85.33 & 5.33 & 2.67 & 34.33 & 58.23 & 5.97 & 1.49 \\
\hline & $15-30$ & - & 85.74 & 9.52 & 4.76 & 65.50 & 24.10 & 10.40 & - \\
\hline C & $0-15$ & 3.13 & 92.05 & 4.90 & 0.35 & 3.23 & 86.10 & 10.80 & - \\
\hline & $15-30$ & - & 82.97 & 14.90 & 2.13 & 3.40 & 78.80 & 17.80 & - \\
\hline
\end{tabular}

W- Woody Species, H- Herbaceous species, G- Grass species, C- Climber species. A- Regrowth Forest physiognomy, BCocoa Plantation physiognomy, C- Tree-Fallow physiognomy. 


\section{DISCUSSION}

The composition of seed bank may reflect the richness of species present in a particular vegetation and its surroundings (Cabin et al., 2000). Similar to the previous findings (Akinyemi and Oke 2013; Olatunji et al., 2015), the present study revealed that in all the physiognomies, seeds from herbaceous plants were the earliest seedling to emerge from the seed bank. This indicated that like many other ecosystems, the seeds of herbaceous species at Ibodi monkey forest have short periods of dormancy and therefore their seeds were the first set of seeds to meet suitable conditions for germination. Olatunji et al. (2015) reported that herbaceous species such as Chromolaena odorata and Euphorbia heterophylla were the first set of seedlings recorded in the first week of seedling emergence test from soil samples taken from a tropical rainforest in Nigeria. In addition, the observed differences in dominant characteristic of herbaceous species among the physiognomies may be attributed to the varying degree of canopy openings which enhances the dispersal of seeds of these herbaceous species. Particularly, the highest percentage contribution of herbaceous species in physiognomy $\mathrm{C}$ might be attributed to the fallow nature of the site because tree fallow has been left to fallow for about 6 years after long regime of smallholder farming. This possibly led to substantial canopy opening over time, thus paving way for recruitment of seed of herbaceous species. Perera (2005) reported that open canopy forests not only support the growth of pioneer and agricultural weed species, which possess light seeds but also facilitate the air movement and thereby the efficient dispersal of wind dispersed seeds. The extant vegetation in this study is not well represented in the seed bank with a similarity index of $10 \%$. Numerous studies have shown that tropical forests seed bank does not represent the current plant community. Hopfensperger (2007) observed the least similarity between the standing vegetation and its associated seed bank in forest ecosystems, after reviewing 108 studies carried out between 1945 and 2006. This agrees with Grombone Guaratini et al. (2004) who recorded a similarity index of $5 \%$ and $11 \%$ in the wet and dry season respectively. Other workers like Sandrine et al. (2005), Taye (2006), Augusto et al. (2009) have also established a low similarity between seed bank and standing vegetation.

Few pioneer woody species such as Trema orientalis, Ficus spp, Maesopsis eminni may be attributed to several factors including failure of the seed of woody plant to store in soil due to consumption by predators e.g. Monkeys, which is very likely in the case of Ibodi Monkey Forest Reserve, low seed production, lack viable seeds in the soil seed bank or the lack of definite mechanism for breaking dormancy (Oke et al., 2007; Akinyemi and Oke 2013). The results of this study indicated that woody species are not maintained as long term component of the soil seed bank of Ibodi monkey forest, which might make the restoration of this forest after anthropogenic activities more difficult (Middleton, 2003). Also, mature forests generally consist of a small seed bank composed of species not present in the standing vegetation due to the fact that most shade-tolerant species do not develop persistent seed banks (Liu et al., 2007). Other studies also suggest that the few woody species are present in the soil seed banks as the seeds of many primary woody species rarely occur in the soil due to large seed size, high water content and rapid germination strategies (Wills and Read, 2007). The presence of invasive species has significant implication on the restoration of a disturbed vegetation, although our emphasis is not on alien species however we did encounter invasive species (Chromolaena odorata) but they made up less than $5 \%$ of the seed bank thus indicating less threat to the extant vegetation.

The soil seed bank across the three physiognomies exhibited a fairly considerable amount of buried viable seeds belonging to 
various species and varying in seed number. In the study sites, the total seed density varied from 63 seeds $/ \mathrm{m}^{2}$ in physiognomy B to 1062 seeds $/ \mathrm{m}^{2}$ in physiognomy $\mathrm{A}$, which was closer to seed density $\left(1052.6 \mathrm{seeds} / \mathrm{m}^{2}\right)$ reported by Mohammed and Hussein (2008) for Elain Natural Forest Reserve in Sudan. The lower seed density in this study may be attributed to several factors such as the modes of production of seeds and dispersal (GromboneGuaratini et al., 2004), shorter duration of time for seedling emergence (Liu et al., 2007) or temporal and spatial heterogeneity of soil seed banks (Taye, 2006). The observed lower seed density confirmed the influence of anthropogenic disturbance among the physiognomies. This suggested that the observed logging disturbance among the physiognomies, possibly led to increase in soil erosion which consequently eliminated seeds of many plant species from the soil seed bank, especially those that are not adapted to anaerobic conditions (Akinyemi and Oke, 2013).

Seed germination and emergence are influenced by the position of seeds in the soil seed profile (Traba et al., 2004). Similar to previous findings, the present study revealed that the seed density of Ibodi monkey forest decreases with increasing depth, which implies that seeds were more concentrated in the upper soil layer $(0-15 \mathrm{~cm})$ than at deeper soil depths (15-30 cm) (Oke et al., 2007; Vandvik et al., 2016). This indicated an inverse relationship between the soil seed bank and the soil depth. This pattern could be attributed to historical changes in the aboveground vegetation and seed bank regime (Oke et al., 2007), seed mass and shape (Liu et al., 2007) as well as vertical transport of seed by earthworms (Curry and Schmidt 2007), and possibly by the burrowing rodents. A depth-related decrease in soil seed bank has been documented (Olatunji et al., 2015), which, in some cases has been linked to the ability of seeds from some species to germinate and emerge (Pons 2000). According to Benvenuti et al. (2001), the depth does not appear to have much or any effect on seed germination but not too surprisingly depth does play a role in seedling emergence. Therefore, the low seed bank density observed with increasing depth irrespective of the physiognomies could be attributed to roles that depth plays in seedling emergence. It can further be attributed to the depth of buried seed which affect seedling emergence by influencing germination via environmental factors such as light, oxygen, temperature, moisture, etc. (Baskin and Baskin 2001). The depth to which seeds are distributed in the soil might have a lot of implications for successful regeneration. Furthermore, the lower seed density in the Cocoa plantation compared with the other physiognomy might be attributed to the anthropogenic disturbances going on at this part of the forest. These activities range from fuel wood gathering to continuous clearing of vegetation to make way for the plantation species (Theobroma cacao) growing, new seedlings being introduced and may be due to the pesticides sprayed on cocoa trees during the insect and fungi control of the trees.

Among other factors, seasonality is one of the most important factors strongly controlling the abundance, species richness, and distribution of plants in forests (Schnitzer, 2005; Dewalt et al., 2010). To understand the role of soil seed bank in population recruitment and vegetation restoration, it is important to describe the spatial and temporal pattern of seed banks. Soil seed banks vary in species composition and abundance across seasons and year (Yan et al., 2009). Fan et al. (2018) in their studies of the Factors influencing the natural regeneration of the pioneering shrub Calligonum mongolicum in sand dune stabilization plantations in arid deserts of northwest China alluded that seasonality was an important factor in seed bank dynamics than site differences. Also, in this study, the total seed density of Ibodi monkey forest varied with season as well as with the physiognomies. The finding of this study revealed that total Seed bank density 
was significantly higher in dry season compared with rainy season in Regrowth forest and Tree Fallow, suggesting that most plants species seeded and dispersed their seeds at the beginning of dry season in order to survive low moisture regime. The seeds met favourable environmental conditions during seedling germination test which eventually led to establishment of their species. On the other hand, the low seed density observed with seedling germination for the soil collected during rainy season, may be due to the germination of most seeds during this period, which resulted in the reduction in the amount of seed buried in the soil. It may also be attributed to erosion and flooding which may likely remove seeds and suffocate some seeds deposited in the seed bank, thus reducing the seed density. This agreed with Grombone-Guaratini et al. (2004) who reported that seed density in dry season was higher than that of rainy season in the seed bank of a gallery forest in Southeastern Brazil. Williams et al. (2005) in their study of soil seed banks in a tropical savanna discovered that the germinable soil seed bank varied seasonally. They recorded highest species richness in seed bank collected in the mid and late dry season compared with the wet season and early dry season.

\section{Conclusion}

The species composition of soil seed bank varied with season as well as with physiognomies. The findings suggest that the different degrees of disturbance among the three physiognomies may possibly contribute to the observed differences in their seed bank composition. The result further revealed that irrespective of the physiognomies, seeds were more concentrated in the upper soil layer than the lower soil layer. Seedbank is often assumed as the basis for regeneration and reconstruction of degraded forest. However, the relatively large number of herbaceous species found in this study compared with woody species suggested that depending soil seed bank to regenerate degraded ecosystem may result into restoration failure. Consequently, the need for research on regenerating species and establishment of propagation techniques should be intensified.

\section{COMPETING INTERESTS}

The authors declare that they have no competing interests.

\section{AUTHORS' CONTRIBUTIONS}

A.A and S.O designed the experiment. A.A, E.T and O.A carried out the experiment, collected and collated data from the field. A.A, O.A and D.S analyzed the data and wrote the manuscript. S.O and E.T revised the manuscript.

\section{ACKNOWLEDGMENTS}

The authors want to specially acknowledge Gabriel Ibhanessebor former curator at IFE Herbarium for assisting in enumeration of the standing vegetation and identifying emerged species from the seed bank. The study did not receive any grant from funding agencies in the public, commercial, or not-for profit sectors.

\section{REFERENCES}

Akinyemi DS, Oke SO. 2013. Soil Seedbank Dynamics and Regeneration in three different physiognomies in Shasha Forest reserve in Southwestern, Nigeria. Ife J. Sci., 15:2-11. DOI: https://scholar.oauife.edu.ng/ijs/files/akin yemi_and_oke_16.pdf

Alexander HM, Foster BL, Ballantyne F, Collins CD, Antonovics J, Holt RD. 2012. Metapopulations and metacommunities: combining spatial and temporal perspectives in plant ecology. Journal of Ecology, 100(1):88-103. DOI:https://onlinelibrary.wiley.com/doi/ pdf/10.1111/j.1365-2745.2011.01917.x

Augusto U, Tigabu M, Odén PC. 2009. Soil Seed Banks and Regeneration of Neotropical Dry Deciduous and Gallery Forests in Nicaragua. Bois et Forêts Des Tropiques, 299(1):1999-2000. DOI: 
https://orbi.uliege.be/bitstream/2268/227 525/1/Uasuf\%202009.pdf

Baskin CC, Baskin JM. 2001. Seeds Ecology, Biogeography, and Evolution of Dormancy and Germination. Academic Press: San Diego, CA, USA.

Benvenuti S, Macchia M, Miele S. 2001. Quantitative analysis of emergence of seedlings from buried weed seeds with increasing soil depth. Weed Science, 49:528-535.

DOI:

http://www.jstor.org/stable/4046486.

CBD. 2012. Aichi biodiversity targets, convention of biological diversity. http://www.cbd.int/sp/targets.

Caballero I, Olano JM, Lizuriaga AL, Escudero A. 2005. Spatial coherence between seasonal seed banks in a semiarid gypsum community: density changes but structure does not. Seed Science Research, 15: 153-160. DOI: 10.1079/SSR2005206

Cabin RJ, Marshall DL. 2000. The demographic role of soil seedbank I. Spatial and temporal comparison of below and above ground population of Desert mustard Lesquerella fendleri. $J$. Ecol., $\quad$ 88:283-292. DOI: https://besjournals.onlinelibrary.wiley.co $\mathrm{m} / \mathrm{doi} / \mathrm{pdf} / 10.1046 / \mathrm{j} .1365$ -

2745.2000.00444.X

Curry JP, Schmidt O. 2007. The feeding ecology of earthworms-a review. Pedobiologia, $\quad$ 50(6):463-77. DOI:10.1016/j.pedobi.2006.09.001

De Villers AJ, Van Rooyen MW, Theron GK. 2002. Seed bank classification of the strandveld succulent karoo, South Africa. Seed Science Research, 12:57-67. DOI: https://doi.org/10.1079/SSR200198

DeWalt SJ, Schnitzer SA, Chave J, Bongers F, Burnham R.J, Cai Z, Chuyong G, Clark DB, Ewango CEN, Gerwing JJ, Gortaire E, Hart T, Ibarra-Manríquez G, Ickes K, Kenfack D, .Macía MJ, Makana JR, Martínez-Ramos M, Mascaro J, Moses S, Muller-Landau HC, Parren MPE, Parthasarath N, Pérez-Salicrup
DR, Putz FE, Romero-Saltos H, Thomas D. 2010. Annual rainfall and seasonality predict Pan-tropical patterns of liana density and basal area. Biotropica, 42: 309-317. DOI: $10.1111 / \mathrm{j} .1744-$ 7429.2009.00589.x

Fan B, McHugh AD, Guo S, Ma Q, Zhang J, Zhang X, Zhang W, Du J, Yu Q, Zhao C. 2018. Factors influencing the natural regeneration of the pioneering shrub Calligonum mongolicum in sand dune stabilization plantations in arid deserts of northwest China. Ecology and Evolution, 8(5): 2975-2984. DOI: 10.1002/ece3.3913

FAO/UNESCO. 1988. FAO-Unesco Soil Map of the World, Revised Legend. World Soil Resources Report 60. FAO, Rome.

FAO. 2010. The second report on the state of the world's plant genetic resources for food and agriculture. Food and Agriculture Organization of the United Nations, Rome, Italy. DOI: https://doi.org/10.1017/S0014479711000 275

Gbetoho AJ, Aoudji AKN, Koura K, GourletFleury S, Kenfack D, DeCanniere C, Ganglo JC. 2017. Floristic and structural changes in secondary forests following agricultural disturbances: the case of Lama Forest reserve in Southern Benin. Int. J. Biol. Chem. Sci., 10(4):1602-1616. DOI: http://dx.doi.org/10.4314/ijbcs.v10i4.13

Greene C, Waters M. 2001. Soil seed bank diversity and abundance in agricultural and forested areas sampled on the domain of the University of the South Sewanee. Journal of Biological Research 2 (http://www.sewanee.edu/biology/journal/). Grombone-Guaratini MT, Leitão-Filho HF, Kageyama PY. 2004. The seed bank of a gallery forest in southeastern Brazil. Brazilian Archives of Biology and Technology, 47: 793-797. DOI: http://dx.doi.org/10.1590/S151689132004000500015 
Golos JP, Dixon WK, Erickson ET. 2016. Plant recruitment from the soil seed bank depends on topsoil stockpile age, height, and storage history in an arid environment. Restoration Ecology, 24(2): $\quad 53-61 \quad$ DOI: https://doi.org/10.1111/rec.12389.

Hopfensperger KN. 2007. A review of similarity between seed bank and standing vegetation across ecosystems. Oikos, 116: 1438-1448. DOI: 10.1111/j.2007.0030-1299.15818.x

Liu Z, Yan Q, Li X, Ma J, Ling X. 2007. Seed mass and shape, germination and plant abundance in a desertified grassland in northeastern Inner Mongolia, China. J. Arid Environ, 69(2): 198-211.

DOI: 10.1016/j.jaridenv.2006.09.012

Lopez RP. 2003. Soil seedbanks in the semiarid Prepuna of Bolvia. Plant Ecol., 168: 85-92.

DOI:

https://link.springer.com/article/10.1023/ A:1024490312759

López-Marinò A, Luis-Calabuig E, Fillat F, Bermudez F. 2000. Floristic composition of vegetation and the soil seed bank in pasture communities under different traditional management regimes. Agr. Ecosyst. Environ., 78:273-282.

Martínez-Ramos M, Ortiz-Rodríguez I, Piñero D, Dirzo R, Sarukhán J. 2016. Anthropogenic disturbances jeopardize biodiversity conservation within tropical rainforest reserves. Curr. Issues, $\mathbf{1 1 3}$ (19): 5323-5328. DOI: www.pnas.org/cgi/doi/10.1073/pnas.160 2893113

Mayor J, Pyott WT. 1966. Buried viable seeds in two California bunch grass sites and their bearing in the definition of a flora. Vegetation, 13: 253-282.

Middleton BA. 2003. Soil seed banks and the potential restoration of forested wetlands after farming. Journal of Applied Ecology, 40(6): 1025-1034. DOI: https://doi.org/10.1111/j.13652664.2003.00866.x
Mohammed H, Hussein M. 2008. Temporal and Spatial variation in soil seed bank in Elain Natural Forest Reserve North Kordofan, Sudan. In Conference on International Research on Food security, natural resource Management and Rural Development.

http://www.tropentag.de/2008/abstracts/ posters/97.pdf

Oke SO, Ayanwale TO, Isola OA. 2007. Soil seedbank in four contrasting plantations in Ile-Ife area of Southwestern Nigeria. Research Journal of Botany, 2: 13-22. DOI:

http://docsdrive.com/pdfs/academicjourn als/rjb/2007/13-22.pdf

Olatunji OA, Oke SO, Isola EF, Akinyemi DS, Omodara AA. 2015. Relationship between the Standing Vegetation, Soil Properties and Soil Seed bank of an industrially degraded Vegetation of Iron Smelting Factory. Int. J. Biol. Chem. Sci., 9(2): 614-632. DOI: http://dx.doi.org/10.4314/ijbcs.v9i2.4

Perera GA. 2005. Diversity and dynamics of the soil seed bank in tropical semideciduous forests of Sri Lanka. Tropical Ecology, 46(1): 65-78.

Pons T. 2000. Seeds: The Ecology of Regeneration in Plants Communities (ed. M. Fenner) CAB International, Wallingford, UK.

Prance GT, Beentje H, Dransfiedl J, Johns R. 2000. The Tropical flora remains undercollected. Ann Missiri Bot Gard, 87: 67-71. DOI: http://biostor.org/reference/13099

Sanderson MA, Soder N, Brzezinski L, Muller L, Skinnners RH. 2004. Plant species diversity influences forage production performance of dairy cattle on pasture. Grassland Sci. Eur., 9: 632-634. DOI: https://www.cabdirect.org/cabdirect/200 53181697

Sandrine G, Shyam SP, Nico K. 2005. Depth distribution and composition of seed banks under different tree layers in a managed temperate forest ecosystem. 
Acta Oecologica, 29: 283-292. DOI:10.1016/j.actao.2005.11.005

Schnitzer SA. 2005. Disentangling above- and below-ground completion between lianas and trees in a tropical forest. J. Ecol., 93: 1115-1125. DOI: $10.1111 / \mathrm{j} .1365-$ 2745.2005.01056.x

Taye J. 2006. Canopy gap regeneration and dynamics in the afromontane Forest of Bale Mountains. Unpublished Thesis. School of Graduate studies Addis Ababa University.

Traba J, Francisco MA, Begoña P. 2004. From what depth do seeds emerge? A soil seed bank experiment with Mediterranean grassland species. Seed Science Research, 14: 297-303. DOI: 10.1079/SSR2004179

Vandvik V, Klanderud K, Meineri E, Maren EI, Topper J. 2016. Seed banks are biodiversity reservoirs: species-area relationships above versus below ground. Oikos, 125: 218-228. DOI: 10.1111/oik.02022
Wills TJ, Read J. 2007. Soil Seed Bank dynamics in post-fire heathland succession in South-Eastern Australia. Plant Ecol., 190: 1-12. DOI 10.1007/s11258-006-9186-4

Williams PR, Congdon RA, Grice AC, Clarke PJ. 2005. Germinable soil seed banks in a tropical savanna: seasonal dynamics and effects of fire. Austral Ecol., 30: 7990.

DOI:

http://www.academia.edu/download/451 55479/Germinable_soil_seed_banks_in_ a_tropical20160427-21584-162abdf.pdf

Yan QL, Liu ZM, Zhu JJ. 2009. Temporal variation of soil seed banks in two different dune systems in bortheastern Inner Mongolia, China. Environ. Geol., 58: $615-624$. DOI 10.1007/s00254-008$1535-2$ 